\title{
AN EMPIRICAL ANALYSIS OF FACTORS INSPIRING STUDENTS FOR ADMISSION IN DISTANCE EDUCATION PROGRAM AT BANGLADESH OPEN UNIVERSITY: \\ A CASE STUDY
}

By

Serazul Islam*

\begin{abstract}
Distance Education System is becoming very popular in Bangladesh because of its increasing demand in the community and other sectors. The study took a descriptive research design and the main data collection instrument was semistructured questionnaire. The sample consisting of 325 respondents was drawn from prospective students called for viva-voce, the final selection stage of the MBA program of Bangladesh Open University (BOU) using simple random sampling technique. Data was analyzed by use of descriptive statistics and factor analysis. The study discovered five critical factors that led growing interest among (MBA) distance education program aspirants at BOU of which institutional reputation was marked as the first and the most important leading factor. This was followed by the career development factor. Students' selfdevelopment and flexible open and distance learning system were the third and fourth interest growing leading factors respectively. Another important factor that the students cited regarding their motivation to opt for admission into distance education program of Distance Education program of MBA at BOU was their academic achievement.
\end{abstract}

Keywords: Growing interest, leading factors, aspirants, Distance Education Program

* Associate Professor, School of Business, Bangladesh Open University, Gazipur-1705, Bangladesh 


\section{Introduction}

MBA, a post-graduate degree in business, stands for Master of Business Administration and is being highly sought-after by business students worldwide. Many companies as well as business and management professionals irrespective of the economy and industry throughout the world highly regard an MBA. The fresh graduates and the working executives prefer MBA program for enhancement of their skills. Businesses are now hiring professionals who can forecast the effect of internal and external forces on their business performance. The growth in international trade has compelled firms to hire personnel with managerial skills at an international business level. Nowadays, MBAs focus not only on the general business management but also on other aspects of business, such as human resource management, marketing, accounting, economics, finance and banking, e-commerce, management information systems, etc. The MBA program gives students all the knowledge they need, both practical and theoretical, to succeed in the world of business and management. Niyaribo, at all. (2012) express people believe that they can increase their competitiveness and future career by improving their knowledge and skills and upgrading their qualifications and help to create chances of their future life success. Although the MBA program lasts only one or two years, the experiences and knowledge one gains will last a lifetime. An MBA can be completed on a campus or distance or online delivery system. Students are much in favor of having their MBA degree in the distance learning mode because of flexibility and convenient time schedule learning through distance learning is becoming popular (Cirtin, 1996). Attending classes at particular time is not a requirement of Distance education (Hegarty, 1996). Leung, a spokesman of Hong Kong Management Association (Kerr, 1995), stated "Unlike postgraduate students in most other countries, Hong Kong people are keen to study to equip themselves for promotion and career development; but they don't want to leave their jobs and ruin chances of promotion and stable incomes."

In Bangladesh all public and private universities have introduced MBA programs in various business disciplines, durations and modes. Bangladesh Open University (BOU), established in 1992, is a unique public university of the Country which is transforming the country's vast human resources into an educated and trained work-force by providing a wide range of academic programs through open and distance learning system. Since students are not required to attend the class regularly. In distance education system rather they can learn at their home or work place with the provided specially designed learning materials. However, the tutorial supports are being provided at study center of BOU to solve difficult concepts of the contents. Beside with the provided learning material, the students can also take the help from regularly broadcasted audio and video programs. School of Business (SOB) at BOU, has been offering 'Regular MBA Program' since 1998. It has created the educated and skilled manpower throughout the country by making business education accessible to a large number of population through its programs. MBA is a 60 credit-hour program comprised of 20 courses. A student can complete this program in minimum 4 semesters (two years) from the date of his/her admission/registration (Student Handbook, MBA program). BOU has another MBA program titled Commonwealth MBA Program which is offered for the employed people with a duration of at least two years. This research study explores a range of factors leading the prospective aspiring students who applied and were called for final selection in 'Regular MBA Program' of BOU only. The review of literature led to the development of the conceptual framework. In the present study, students wishing to enroll for MBA as their preferred choice of study are referred to as MBA aspirants. At home and abroad, considerable studies were done on open and distance education system but very few of them were on distance MBA programs and no specific study was conducted in 
Bangladesh on the conducing factors to admission in distance MBA program. The present study has, therefore, been undertaken to abridge the gap.

\section{Literature Review}

Numerous studies were accomplished on open and distance learning but the number of studies on distance learning MBA programs are scanty. The studies, however, pertinent to the present study are reviewed below:

The previous studies reflected similarities and dissimilarities in the results. Before launching a new MBA program, Beck and Williams (1989) In a survey has identified job performance as the prime leading factor and career development as the second most important motivating factor for pursing MBA. Similarly study of Luker et al. (1989) discovered the factors names as; attaining long-term career objectives, getting promotions, remaining competitive, getting better pay and having personal satisfaction as the top five reasons for pursuing MBA. On the other hand several studies (Carpenter, 1997; Horowitz, 1997; MacErlean, 1993), explored that developing a better network and getting a better job and pay were the most common motivations.

Many people believe that a MBA degree holder can achieve fast track career because of improved salary and quickly climbing the career ladder (Baruch and Peiperl, 2000). Students inspire and pursue MBA degree which ensure their career development through achieving organizational goal, employers search for educated and skilled manpower.

Lin and Tsai (2008) say 'gaining higher status' a pragmatic motivation factor of learning management. Teowkul et al. (2009) found no differences in motivation factors for Master and Doctoral degrees between male and female students at Open University of Thailand. The findings revealed that master degree students of distance education expect more compensation, easy jobs change and smooth transition into new careers.

Briggs (2013) identified that the prospective students were motivated to pursue an MBA degree for earning, advanced degree, earning more money, changing careers, advancing their careers by obtaining a required credential and obtaining business management knowledge. The results of the study of Anwer, Nas and Raza (2013) revealed that career growth, knowledge \& skills, higher salaries, high education and flexibility and proximity are the basic motives to opt MBA evening program in different private universities of Islamabad.

Taiwan, Kung (2002) identified the factors that affected the students' decision to distance learning courses. These factors, as she found, were interest in the subject matter, cost of the program, flexibility of time, reputation of the course, course teachers and school, not having to be physically present in the class, LeBlanc and Nguyen (1999) found the relationship between price and quality, as well as social and emotional value as the influencing factors to the students to pursue a program. In their study it was also revealed that male and female students are more inclined towards social value while female showed concerns about price and quality relationship. Joseph and Joseph (2000) identified some the critical some factors relating to the students' choice of a university such as encompassing, availability of information on course, possibility of getting a job or career advancement as well as the physical aspects and facilities of the learning institution. While Miller (1988) found accreditation, teaching methods, program duration, fields 
of specialization, school ranking and cost as important considerations for pursuing a program in a university. Results of the study by Powers (1988) revealed the academic quality, reputation of the faculty and placement opportunities being highly rated leading factors for selecting a university for study. Results of a survey of 152 students by Parker et al. (1989) indicated that educational attainments of faculty, image of the university, placement records, researches done by the faculty and tuition costs were the most important criteria for selecting a university. Linden et al. (1992) suggested that prospective students should consider placement records, tuition fees and average GMAT scores. Webb and Allen (1994) examined similar issues and found academic reputation, accreditation and tuition as highly ranked factors. Panitz (1995) surveyed 114 parttime MBA students at various stages in their MBA programs, and found that these students wanted to study under experienced professors who had vast theory knowledge and impart quality instruction. In addition, staff professionalism, supporting facilities, ethical standards and the image of the school were also considered as important.

In his study Briggs (2013) found a most important university related factor that prospects considered for admission into MBA program was the university's ability to help them in becoming more marketable or advance their career. Other also recognize factors in clued the cost, university's reputation, convenience, program duration, the university's location, and the caliber of peers in the classroom as the motivating factors towards admission into MBA program.

Empirical review of literature revealed substantive information on other countries but no literature existed in Bangladesh on the present topic. It was with this understanding and the antecedent developments that the study sought to examine what motivated students to apply for MBA program at BOU.

\section{Objectives}

The present study aimed primarily at examining the factors that led aspiring students to pursue MBA program at BOU. Following were specific objectives of the study:

1. To explore the demographic characteristics of the selected aspiring MBA students; and

2. To investigate into the dominating factors towards growing of students' interest for admission into MBA program at BOU.

\section{Methodology}

The present study adopted a descriptive research design. The methods followed in carrying out the study are as follows:

\section{Sample Design}

At present BOU has 5 study centers for regular MBA program throughout the country (Student Handbook, MBA program). For admission into the first intake (131 semester) of this program, the applicants were 1,080, of which 751 students, after preliminary screening, were called for viva-voce, the final selection stage for admission(Official documents of SOB, BOU). These students constituted the sample population of the present study. Using simple random sampling technique, a total number of 325 respondents were used as a sample size. The above sample is in 
line with Roscoe's (1975) rule of thumb that sample size between 30 and 500 is adequate for this kind of study.

\section{Types and Sources of Data}

The types and sources of data used in the study comprised of both primary and secondary. Students expected to get them admitted into regular MBA program of BOU were the sources of primary data, while the sources of secondary data comprised of articles, student handbook, MBA prospectus, official documents of SOB, journals, website, research reports and other publications.

\section{Data Collection Instruments and Procedure}

A semi-structured questionnaire was constructed and used as an instrument of collecting primary data from the sample aspiring students. The questionnaire was composed of two sections. The first section solicited personal data from the respondents with open and close ended questions. The questions in the next section consisted of twenty five statements with close-ended questions regarding the motivating factors. The respondents were asked to indicate how strongly they agree or disagree with each factor using the five point Likert type scale with from 1 (strongly disagree) to 5 (strongly agree) by putting a tick for each factor. To the end the aspiring MBA students were given questionnaire before appearing the viva board and they themselves filled up the questionnaire. In the study, the content validity of questionnaire was tested with a group of students through e-mail survey in advance. The most common internal consistency and reliability is Cronbach's alpha. By convention, a lenient cut-off 0.60 is common in exploratory research. In this study we obtained a Cronbach's alpha coefficient of 0.62 was attained for these items. Since the Cronbach's alpha coefficient is greater than 0.60 , thus it has reliability.

\section{Data Processing and Analysis}

The data collected through administering questionnaire were checked to ensure the completeness, consistency and readability. The values of the variables were coded by numerical figures and the numerical coded numbers were given input for analysis of the data using personal computer. Data were then analyzed by using Statistical Package for Social Science (SPSS), version 16. In order to explore the background information of the aspiring MBA students, descriptive statistics comprising of simple percentage, frequency, and mean was used in the present study. Factor analysis was done to find out the leading motivating factors to the interested students. Since Liker Scale produces ordinal data only, parametric test (e.g. t-test) could not be used.

\section{Results and Discussion}

The results of the present study derived from the field survey are discussed below with help of both descriptive statistics and factor analysis.

\section{Descriptive Statistics}

Descriptive statistics can be used to summarize the data, either numerically or graphically, to describe the sample. In the present study, the numerical descriptors, the frequency distribution, percentage and mean were used. Several driving factors lead students to opt for admission into MBA program including their socio-economic and academic background. Here's a look at the prominent characteristics possessed by the aspiring MBA students: 
Table 1

Demographic Characteristics of the Sample Students $(\mathbf{N}=325)$

\begin{tabular}{|c|c|c|}
\hline Characteristics & $\mathbf{N}$ & Percentage \\
\hline \multicolumn{3}{|l|}{ Gender } \\
\hline Male & 283 & 87.1 \\
\hline Female & 42 & 12.9 \\
\hline \multicolumn{3}{|l|}{ Age (Years) } \\
\hline Below 30 & 155 & 47.7 \\
\hline 30-35 & 106 & 32.6 \\
\hline $35-40$ & 40 & 12.3 \\
\hline 40 and above & 24 & 7.4 \\
\hline \multicolumn{3}{|c|}{ Mean age 31.36 years } \\
\hline \multicolumn{3}{|c|}{ Previous Educational Qualification } \\
\hline Graduation (Pass) & 70 & 21.5 \\
\hline Graduation (Hons.) & 88 & 27.1 \\
\hline Masters & 167 & 51.4 \\
\hline \multicolumn{3}{|l|}{ Area of Graduation } \\
\hline Science & 136 & 41.8 \\
\hline Business studies & 84 & 25.8 \\
\hline Humanities & 105 & 32.3 \\
\hline \multicolumn{3}{|l|}{ Previous University } \\
\hline BOU & 11 & 3.4 \\
\hline National & 152 & 46.8 \\
\hline Other public universities & 122 & 37.5 \\
\hline Other private universities & 40 & 12.3 \\
\hline \multicolumn{3}{|l|}{ Marital Status } \\
\hline Single & 138 & 42.5 \\
\hline Married without children & 67 & 20.6 \\
\hline Married with children & 120 & 36.9 \\
\hline \multicolumn{3}{|l|}{ Present Occupation } \\
\hline Unemployed & 48 & 14.8 \\
\hline Govt. job & 91 & 28.0 \\
\hline Private job & 175 & 53.8 \\
\hline Business & 11 & 3.4 \\
\hline \multicolumn{3}{|l|}{ Job/Business Status } \\
\hline Full time & 254 & 91.7 \\
\hline Part time & 23 & 8.3 \\
\hline \multicolumn{3}{|l|}{ Professional Experience } \\
\hline Below 5 years & 154 & 55.6 \\
\hline 5 years to 10 years & 71 & 25.6 \\
\hline 10 years and above & 52 & 18.8 \\
\hline \multicolumn{3}{|c|}{ Mean experience 6.48 years } \\
\hline \multicolumn{3}{|l|}{ Annual Income } \\
\hline Below Tk.100,000 & 28 & 10.1 \\
\hline
\end{tabular}


$\begin{array}{lcc}\text { Tk. } 100,000 \text { to Tk. } 200,000 & 93 & 33.6 \\ \text { Tk. } 200,000 \text { to Tk. } 300,000 & 89 & 32.1 \\ \text { Tk. } 300,000 \text { and above } & 67 & 24.2\end{array}$

Mean income Tk.25,4301.13

\section{Father's/Husbands' Occupation}

$\begin{array}{lcc}\text { Agriculture } & 92 & 28.3 \\ \text { Govt. job } & 104 & 32.0 \\ \text { Private job } & 58 & 17.8 \\ \text { Business } & 71 & 21.8 \\ \text { Influencing Person } & & \\ \text { Myself } & 250 & 76.9 \\ \text { Family Members } & 32 & 9.8 \\ \text { Colleagues } & 19 & 5.8 \\ \text { Boss/Management } & 7 & 2.2 \\ \text { Friends/Relatives } & 17 & 5.2 \\ \quad \text { Source: Field Survey } & & \end{array}$

The demographic information of the respondents is represented in Table 1 based on frequency distributions and percentages. From the (325) respondent aspiring MBA students in this study 87.1 percent were found to be male and only 12.9 percent were female, which indicates the traditional male dominated sample in Bangladesh. Four-fifth of the respondents (80.3 percent) was up to 35 years old. The average age (31.36 years) of the sample respondents indicates the young students' interests for participation in the MBA program. Interestingly, more than onehalf of the aspiring respondents applied for the admission into BOU's MBA program after completion of their master degree. Though the courses designed for the MBA program are mostly favorable for business graduates, the majority of the aspiring students (74.15 percent) were graduated from either science or humanities group. Regarding the previous university from where the aspirants were graduated, it is noticed that the highest percent of respondents of them were from public universities which accounted for 87.7 percent. About three-fifth of the total respondents were married of which 67.17 percent had children. The greater numbers of aspiring students (85.2 percent) were engaged in either as government or private service holders or as businessmen. But most of the employed aspirants (63.18 percent) were employed in private job and absolute majorities (91.7 percent) were engaged in their activities on full time basis. As is shown in Table 1, more than one half the employed respondents had less than 5 years work experience and 25.6 percent had 5 to 10 years work experience. The rest of the respondents had professional experience of more than 10 years. The average work experience (6.48 years) points that the students either for getting promotion or switching to another job were applied for MBA program with their existing job experience. The government service holders' children applied for the MBA program accounted for 32 percent. Whose parental occupation was agriculture formed the second highest 28.3 percent. Table 1 shows that more than two third of the respondents were motivated by themselves for persuasion of MBA program at BOU. Only 9.8 percent were motivated by their family members. The results, therefore, suggest that the current MBA demanding job market mostly influenced the aspiring young, middle aged employed and married students to opt for admission into MBA program for their present and future career development. 


\section{Factors Analysis}

With a view to examining the factors that impact the students to be interested in pursuing MBA program at BOU, the present study adopted Exploratory Factor Analysis (EFA). The KaiserMeyer-Olkin Measure of Sampling Adequacy (KMO) and a Bartlett's Test were applied as pretests of factor analysis. Generally, a KMO value of greater than 0.5 is desirable.

Table 2

KMO and Bartlett's Test

\begin{tabular}{llr}
\hline Kaiser-Meyer-Olkin Measure of Sampling Adequacy & .725 \\
\hline Bartlett's Test of Sphericity & Approx. Chi-Square & 1497.803 \\
& df & 300 \\
& Sig. & .000 \\
\hline
\end{tabular}

Table 2 shows, in the present study, that the value of the KMO statistic is .725. Thus, the sample was considered adequate for the study to proceed with factor analysis. Bartlett's Test of Sphericity was used to test the null hypothesis that the variables are uncorrelated in the population. The Bartlett's Test showed a .000 significance level. This implies a strong relationship existed among the variables, and hence supports the factor analysis.

\section{Table 3}

\section{Communalities for Extraction}

\begin{tabular}{llrr}
\hline No. & \multicolumn{1}{c}{ Variables } & Initial & Extraction \\
\hline 1 & Standard program structure with modern curriculum & 1.000 & .637 \\
2 & BOU is a unique public university & 1.000 & .585 \\
3 & MBA program of BOU is being well recognized in the job market & 1.000 & .522 \\
4 & Competitive but fair selection process of MBA admission & 1.000 & .538 \\
5 & Getting promotion in the present organization & 1.000 & .723 \\
6 & Switching to another corporate job & 1.000 & .666 \\
7 & Holding the managerial or executive position & 1.000 & .618 \\
8 & Having a job with high salary & 1.000 & .640 \\
9 & Making confidence and competitive to take the forthcoming & 1.000 & .640 \\
& challenges & & \\
10 & Acquiring business management knowledge and developing & 1.000 & .562
\end{tabular}


12 Tuition and other charges of BOU are comparatively low $\quad 1.000 \quad .515$

13 No age barrier to admission into MBA $\quad 1.000 \quad .528$

14 Classes and examinations are on Friday only $1.000 \quad$.517

15 Requirements for admission are flexible $\quad 1.000 \quad .585$

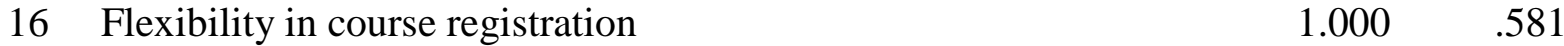

17 Class attendance is not compulsory $\quad 1.000 \quad .681$

18 Flexibility in attending classes and appearing examination at any $\quad$\begin{tabular}{ll}
.588 \\
\hline
\end{tabular} study center

19 Successful completion of another program from BOU $\quad 1.000 \quad 615$

20 Obtaining masters degree as I do not have $\quad 1.000 \quad .511$

21 Passing in the examination from BOU is comparatively easy. $\quad 1.000 \quad$.549

22 Receiving a professional degree required for almost all executive $\quad 1.000 \quad 674$ posts

23 Pursuance of DBA/PhD in the future $\quad 1.000 .587$

24 Starting a new business of own $\quad 1.000 \quad .534$

25 No option to getting myself admitted into another public university $\quad \begin{array}{ll}1.000 & .598\end{array}$

Extraction Method: Principal Component Analysis.

Table 3 exhibits the communalities of the variables which expresses the percentage of each variable's variance that is explained by the extracted factors. For example, the highest 72.3 percent variance of Variable 5 (Getting promotion in the present organization) is explained by the extracted factors. For factor extraction, the most widely used method- Principal Component Analysis (PCA) was applied in the present study. Factor extraction involved the determination of the smallest number of factors that could be used to determine which motivating variables explained the greatest variations in aspiring students' choice of MBA program at BOU.

Table 4

Total Variance Explained

\begin{tabular}{ccccccc}
\hline \multirow{2}{*}{ Component } & \multicolumn{3}{c}{ Initial Eigenvalues } & \multicolumn{2}{c}{ Rotation Sums of Squared Loadings } \\
\cline { 2 - 6 } & \multirow{3}{*}{ Total } & Variance & Cumulative & & \% of & Cumulative \\
& 3.920 & 15.679 & 15.679 & 3.920 & 15.679 & 15.679 \\
\hline 1 & 2.208 & 8.831 & 24.510 & 2.208 & 8.831 & 24.510 \\
2 & 1.716 & 6.864 & 31.374 & 1.716 & 6.864 & 31.374 \\
4 & 1.485 & 5.942 & 37.316 & 1.485 & 5.942 & 37.316
\end{tabular}




\begin{tabular}{lllllll}
5 & 1.393 & 5.572 & 42.888 & 1.393 & 5.572 & 42.888 \\
6 & 1.275 & 5.098 & 47.986 & 1.275 & 5.098 & 47.986 \\
7 & 1.170 & 4.679 & 52.665 & 1.170 & 4.679 & 52.665 \\
8 & 1.099 & 4.396 & 57.061 & 1.099 & 4.396 & 57.061 \\
9 & 1.044 & 4.174 & 61.235 & 1.044 & 4.174 & 61.235 \\
\hline
\end{tabular}

Extraction Method: Principal Component Analysis.

Table 4 reveals the actual components or factors that were extracted. The section labeled "Rotation Sums of Squared Loadings," shows only those factors that met the cut-off criterion (extraction method). In Table 4, it is noticed that the eigenvalues greater than 1 (default option) result in nine factors being extracted. The Scree Plot (Figure 1) also displayed that nine components with eigenvalues greater than 1 of the twenty five variables are extractable for factor analysis. The first component explains a high variance of 3.92, which is 15.68 percent of the total variance. This is the prime leading factor to growing interest among the aspiring MBA students. Likewise, the ninth component explains 4.17 percent of the total variance, and the first nine components together explain 61.24 percent of the total variance (Table 4).

\section{Figure 1}

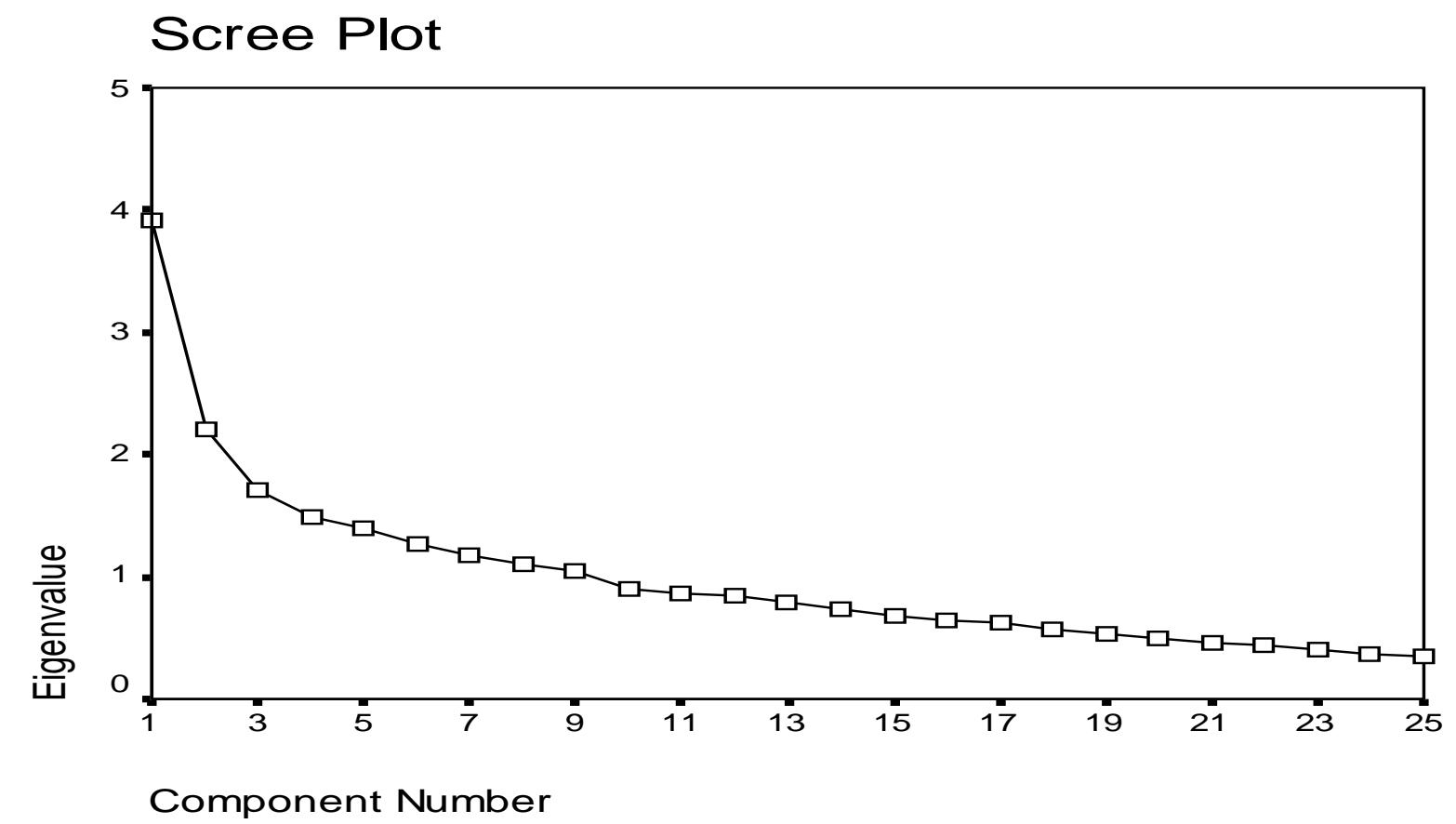

In order to reduce the number of factors and, hence, to enhance the interpretability, factors were rotated using the most commonly used method 'varimax rotation'. Table 5 shows the rotated component matrix which contains the coefficients or factor loadings for each variable. These coefficients, the factor loadings, represent the correlations between the factors and the variables. A coefficient with a large absolute value indicates that the factor and the variable are closely related. The factors can be interpreted in terms of the variables that have large loadings on them. 
The results of varimax rotation is given in Table 5, which shows that five factors constituting the variables with factor loadings of more than 0.5 were identified for interpretation.

Table 5

\section{Rotated Component Matrix (a)}

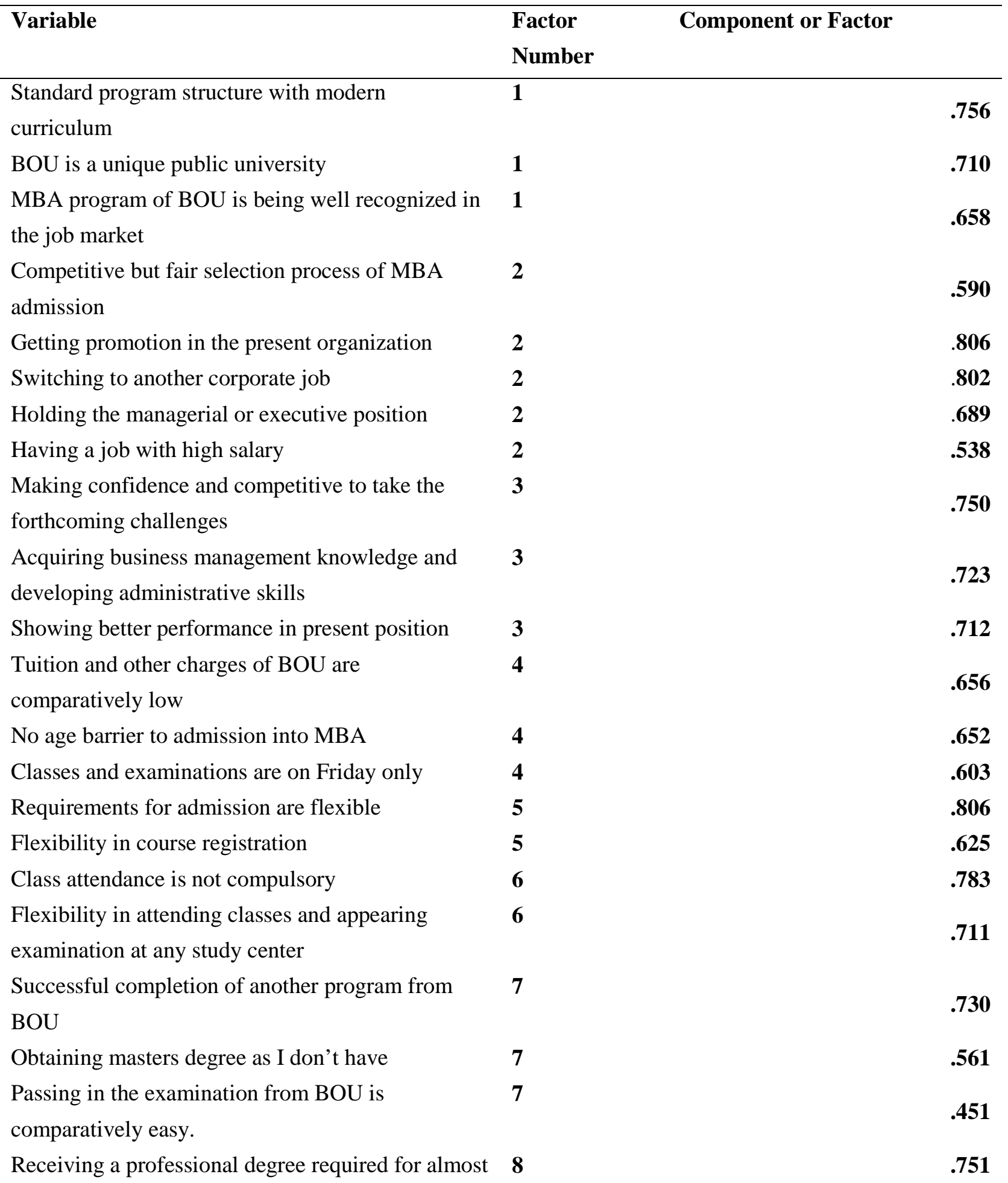


all executive posts

Pursuance of DBA/PhD in the future

To be entrepreneur

No option to getting myself admitted into another

public university

Extraction Method : Principal Component Analysis, Rotation Method : Varimax with Kaiser Normalization.

a Rotation converged in 24 iterations.

As evident in the Table 5, factor 1 has high coefficients for 4 variables (standard program structure, unique university, recognized program, and fair selection process). Therefore, this factor is labeled institutional reputation factor and is the dominant factor explaining the highest 15.68 percent of the total variance. The variables (getting promotion, switching to another job, holding managerial position, having high salary, starting own business) constitute the second factor which is marked career development factor. Factor 3 is composed of the variables with high loadings on it. These variables include making confidence and competitive, acquiring business management knowledge, and showing better performance in the present position. Thus, factor 3 is called self-development factor. Another factor named flexible learning system factor is comprised of seven variables (low tuition fees, no age barrier, weekly holiday classes and examinations, flexible admission requirements, flexibility in course registration, voluntary class attendance, and convenient place for class and examination participation). Five variables (successful completion of BOU's another program, obtaining masters degree, receiving a professional degree, pursuance of $\mathrm{DBA} / \mathrm{PhD}$ in the future) constitute the fifth factor and this is conceptualized as academic achievement factor. Therefore, the factor analysis in the study convincingly suggests that the interests are being grown among the aspiring students for admission into MBA program at BOU by the five leading factors: institutional reputation in terms of modern curriculum, uniqueness and fair selection process, career development, selfdevelopment, flexible learning system, and academic achievement.

\section{Conclusion}

The present competitive and global business environment badly needs the executives with broad knowledge of business and management skills. MBA Distance Education is the best option for those who wish to complete their degree and gain the required skills simultaneously. Bangladesh Open University with the motto of creating next generation business leaders has been offering MBA program since 1998. The study aimed to identify the factors that grew interest among the MBA aspiring students at Bangladesh Open University. The results help to conclude that BOU's prospective students are self motivated as most of them are mature, employed, married, professionally experienced and public university graduates. The factors leading to growing interest among MBA aspirants were characterized by twenty five statements. These factors are together significantly related to the students decision for admission into MBA program. Institutional reputation in the form of standard program structure, recognition, fair selection process and uniqueness is the most significant factor towards growing interest among aspiring MBA students. The career development factors entailing promotion, switching to another corporate job, holding executive position, getting job with high salary, and starting new own 
business also influence the students to take decision taken for admission to MBA program. Students with the ambition of making confidence and competitive, acquiring business management knowledge, and showing better performance in the present position feel interest for admission to MBA program. Flexible learning system comprising of low tuition fees, no age barrier, classes and examinations on weekly holidays, conciliatory admission requirements, flexibility in course registration, voluntary class attendance, and convenient place for class and examination participation contributes to interest growing among MBA aspirants. Successful completion of BOU's another program, obtaining another masters degree earlier, receiving a professional degree, pursuance of $\mathrm{DBA} / \mathrm{PhD}$ etc. as academic achievement factor motivates the students too for admission to MBA program through open and distance learning. Future inquiries could look to find out whether there is a significant difference in leading factors between students of different characteristics.

\section{REFERENCES}

Baruch, Y., \& Peiperl, M. (2000). The impact of an MBA on graduate careers. Human Resource Management Journal, 10(2), 69-90.

Beck, J.E., \&Williams, G.L. (1989). MBA courses don't teach you how to manage - or do they?. Human Resources Journal, 5(2), 15-20.

Boyatzis, R., \& Renio, A. (1989). The impact of an MBA programme on managerial abilities. Journal of Management Development, 8(5), 66-77.

Carpenter, R. (1997). What's an MBA worth?. Canadian Business, 70 (14), 40-42.

Cirtin, A. (1996). The MBA degree on television: The fusion of teaching and technology. T. H.E. Journal, 23, 70-73.

Hegarty, S. (1996). Do MBAs lead to a better job and a bigger salary?. Works Management, 49(2), 61-65.

Horowitz, A. (1997). Is an MBA right for you?. Computerworld, 31(27), 78.

Joseph, M., \& Joseph, B. (2000). Indonesian students' perception of choice criteria in the selection of a tertiary institution: Strategic implications. International Journal of Educational Management, 14(1), 40-44.

Kerr, J. (1995). Part-time study gains popularity. South China Morning Post, 28 July.

Kretovics, M. (1999). Assessing the MBA: What do our students learn?. The Journal of Management Development, 18(2), 125-136.

Kyariacou, C., Coultard, M., Hultgren, A., \& Stephens, P. (2002). Norwegian university student views on a career in teaching. Journal of Vocational Education and Training, 54(1), 103116.

Kung, S-C. (2002). Factors that affect students' decision to take distance learning courses: A survey study of technical college students in Taiwan. Education Media International, 39(3/4), 299-305.doi:10.1080/09523980210166044 
LeBlanc, G., \& Nguyen, N. (1999). Listening to the customer’s voice: Examining perceived service value among business college students. International Journal of Educational Management, 13(4), 187-198.

Linden, D.W., Brennan, J., \& Lane, R. (1992). Another boom ends. Forbes, 20, 76-80.

Lin, H-M., \& Tsai, C-C. (2008). Conceptions of learning management among undergraduate students in Taiwan. Management Learning, 39(5), 561-578.

Luker, A., Bowers, M.R., \& Powers, T.L. (1989). Factors influencing pursuit of the MBA degree: A student and employer perspective. Journal of Marketing for Higher Education, 2(2), 87-96.

MacErlean, N. (1993). Master classes. Accountancy, 111(1195), 29-34.

Miller, E. (1988). Barron's guide to graduate business schools. New York, NY: Barron's Educational Series, Inc.

Ozkale, L., Kusku, F., \& Saglamer, G. (2004). Women in engineering education in Turkey. In proceedings of 2004 American society of engineering education annual conference and exposition: Engineering education reaches new heights, Salt lake city, UT, July 23-26.

Panitz, E. (1995). Part-time MBA student's expectations of their academic experience. Journal of Marketing for Higher Education, 6(1), 87-95.

Parker, R.S., Pettijohn, C., \& Pettijohn, L. (1989). Choosing a business school: The relevant criteria. Journal of Marketing for Higher Education, 2(2), 97-106.

Powers, T.L. (1988). The consumer perspective on business school evaluation. Journal of Marketing for Higher Education, 1(1), 109-131.

Roscoe, J.T. (1975). Fundamental research statistics for the behavioural sciences (2nd ed.). New York: Holt Rinehart \& Winston.

Sturges, J., Simpson, R., \& Altman, Y. (2003). Capitalising on learning: An exploration of the MBA as a vehicle for developing career competencies. International Journal of Training \& Development, 7(1), 53-66.

Teowkul, K. et al. (2009). Motivational factors of graduate Thai students pursuing master and doctoral degrees in business. Ramkhamhaeng University International Journal, 3(1), 25-56.

Webb, M.S., \& Allen, L.C. (1994). Graduate business students: Factors that differentiate diverse market's matriculating decisions. Journal of Marketing for Higher Education, 5(1), 87-107. 